\title{
EFFECTS OF RADIAL GROWTH RATE ON ANATOMICAL CHARACTERISTICS AND WOOD PROPERTIES IN PERONEMA CANESCENS TREES PLANTED IN SOUTH KALIMANTAN, INDONESIA
}

\author{
Ishiguri $\mathrm{F}^{1}$, *, Wahyudi $\mathrm{I}^{2}$, Takashima $\mathrm{Y}^{3}$, Ohshima $\mathrm{J}^{1} \&$ Yokota $\mathrm{S}^{1}$ \\ ${ }^{1}$ School of Agriculture, Utsunomiya University, Utsunomiya 321-8505, Japan \\ ${ }^{2}$ Faculty of Forestry, Bogor Agricultural University, Bogor 16680, Indonesia \\ ${ }^{3}$ Forest Tree Breeding Centre, Forestry and Forest Products Research Institute, Hitachi 319-1301, Japan \\ *ishiguri@cc.utsunomiya-u.ac.jp
}

Submitted February 2020, accepted July 2020

\begin{abstract}
Radial variations of anatomical characteristics and wood properties were investigated for a relatively slowgrowing tropical tree species, Peronema canescens. Based on the results, effects of radial growth rate on anatomical characteristics and wood properties were evaluated. The mean values of stress-wave velocity of stem, vessel diameter, cell wall thickness of wood fibre, wood fibre length, vessel element length, basic density and compressive strength parallel to grain at green condition were $3.94 \mathrm{~km} \mathrm{~s}^{-1}, 201 \mu \mathrm{m}, 2.05 \mu \mathrm{m}, 1.05 \mathrm{~mm}$, $0.21 \mathrm{~mm}, 0.48 \mathrm{~g} \mathrm{~cm}^{-3}$ and $36.9 \mathrm{MPa}$, respectively. No significant correlations were found between growth characteristics (stem diameter at $1.3 \mathrm{~m}$ above ground and tree height) and anatomical characteristics or wood properties. These results suggested that anatomical characteristics and wood properties of this species were independent from growth characteristics, even in relatively slow-growing tree species in the tropics.
\end{abstract}

Keywords: Vessel and fibre morphologies, basic density, compressive strength, radial growth rate, Peronema canescens

\section{INTRODUCTION}

Relationships between radial growth rate and anatomical characteristics or wood properties have been investigated for hardwood species by many researchers (Zobel \& van Buijtenen 1989, Zhang 1995, Lei et al. 1997). Zobel and van Buijtenen (1989) reviewed the relationships between radial growth rate and wood density in hardwoods; there is no apparent relationships in diffuse-porous wood, while increase of growth ring width resulted in increase of wood density in ring-porous wood. Many researchers also focused on the relationships in fast-growing tree species grown in tropical countries (Ohbayashi \& Shiokura 1990, DeBell et al. 2001, Wahyudi et al. 2001, 2016, Kojima et al. 2009a,b, Makino et al. 2012, Pillai et al. 2013, Ishiguri et al. 2016, Hidayati et al. 2017, Pertiwi et al. 2017a,b, 2018). Kojima et al. (2009b) showed that high growth rates did not intrinsically affect the wood properties of fast-growing tropical or subtropical species that has reached harvesting age. On the other hand, in the tropics, non-fast-growing tree species are also important for sustainable forest management. Thus, the relationships should be investigated in non-fast-growing tree species grown in tropical countries.

Peronema canescens is natively distributed in Peninsula Malaysia, Sumatra, Riau Archipelago, West Java and Kalimantan (Soerianegara \& Lemmens 1994). The wood of this species is ring-porous with distinct growth ring, whereas sometimes the ring-porosity becomes obscure under certain growth conditions (Ogata et al. 2008). In addition, the wood is of good quality, being somewhat similar to that of teak (Tectona grandis) (Ogata et al. 2008). Therefore, this species, classified as fancy wood, has been exported at a high selling price, and is one of the preferred species planted in industrial timber estates of Indonesia (Kartawinata 1994). To promote plantation establishment of this species, basic information about wood properties is important. However, available data on anatomical characteristics and wood properties of this species is limited to mean values, ranging from minimum and maximum values, from previous studies 
(Soerianegara \& Lemmens 1994, Ogata et al. 2008). Thus, more detailed data, such as radial variation or among-tree variation is needed for accessing anatomical characteristics and wood properties of this species.

In the present study, radial variation of anatomical characteristics and wood properties were investigated for 23-year-old $P$. canescens planted in Indonesia. Based on the obtained results, the effects of radial growth rate on wood properties were discussed.

\section{MATERIALS AND METHODS}

\section{Field experiments}

Fifty trees of 23-year-old P. canescens in a stand were used for this experiment. The stand was located in Semaras, Pulau Laut, South Kalimantan, Indonesia ( $\left.3^{\circ} 47^{\prime} \mathrm{S}, 116^{\circ} 6^{\prime} \mathrm{E}\right)$, and was initially established by seedlings produced from unknown seed source at $3 \times 3 \mathrm{~m}$ spacing. A plot $(25 \times 25 \mathrm{~m})$ was set in the centre of the stand. Diameter at $1.3 \mathrm{~m}$ above the ground was measured by a tape meter for all trees in the plot. To evaluate the effects of radial growth rate on cell morphologies and wood properties, the trees in the plot were categorised into three groups according to mean $(\mu)$ and standard deviation (SD) of stem diameter (D) in the plot: fast-growing ( $\mathrm{D}>\mu+$ one $\mathrm{SD})$, medium-growing ( $\mu$ - one $\mathrm{SD}<\mathrm{D}<\mu+$ one $\mathrm{SD})$, and slow-growing $(\mathrm{D}<\mu$ - one SD cm) trees (Ishiguri et al. 2012b). Cell morphologies and wood properties were determined for five trees in each category. In addition, tree height was measured for these 15 selected trees by a height meter.

Stress-wave velocity of trees was measured for all trees in the plot according to the method described in previous reports (Ishiguri et al. 2012b, Makino et al. 2012). Sensors of a commercial handheld stress-wave timer were set at 50 to $150 \mathrm{~cm}$ above ground for measuring the stress-wave propagation time. Stress-wave velocity was calculated by dividing distance between sensors $(100 \mathrm{~cm})$ by stress-wave propagation time.

\section{Anatomical characteristics and wood properties}

Core samples ( $5 \mathrm{~mm}$ in diameter) were collected from five tree in each category to examine the anatomical characteristics and wood properties.
Four core samples were collected at $1.3 \mathrm{~m}$ above the ground by an increment borer from each tree and used for the following experiments. Peronema canescens is a ring-porous wood. However, ringporosity sometimes becomes obscure under certain growing conditions (Ogata et al. 2008). In the present study, some growth rings also showed obscure ring-porosity. Due to this reason, wood properties and cell morphologies were determined in relation to distance from pith.

The core samples were cut into small segments at $1 \mathrm{~cm}$ intervals from pith to bark. The obtained small segments included at least one or more growth rings. Transverse sections $(20 \mu \mathrm{m}$ in thickness) were obtained from each segment by using a sliding microtome (ROM-380 or REM-710, Yamatokohki). Transverse sections were stained with $1 \%$ safranin, and dehydrated by graded ethanol. Then, dehydrated sections were dipped into xylene, and mounted on slide glass. Anatomical characteristics, such as vessel diameter in pore zone, and diameter and cell wall thickness of wood fibre, were determined by using digital images obtained by a microscope (BX51, Olympus) equipped with a digital camera (DSE330, Olympus). Radial and tangential diameters of vessels and wood fibre were measured, and the mean values were calculated as vessel diameter and wood fibre diameter. At each radial position, diameters of vessels in pore zone were measured for 30 vessels, and diameter and cell wall thickness of wood fibre was measured for 50 fibres.

Core samples were also cut into small segments at $1 \mathrm{~cm}$ intervals from pith to bark. Small strip specimens for measuring the vessel element length were separately collected from pore of each segment. For measurement of wood fibre length, strips were obtained from outer pore zone of each segment. The obtained small strips for measuring the length of vessel elements and fibres were macerated with Schulze's solution at room temperature for 12 hours, and then at $70{ }^{\circ} \mathrm{C}$ for 1 hour. A microprojector (V-12, Nikon) and a digital calliper (CD-30C, Mitutoyo) was used for measuring the total 30 vessels and 50 fibres in each radial position.

Core samples obtained from five selected trees in each category were used for measuring the basic density and compressive strength parallel to grain, according to the method described in a previous study (Ishiguri et al. 2012b). One-cm long segments from pith to bark were obtained 
from the core samples to measure basic density. Basic density was determined by dividing ovendrying weight by green volume measured by water displacement. A strength testing equipment for core samples (Fractometer II, IML) was employed to measure the compressive strength parallel to grain at green condition. Core samples were cut at $5 \mathrm{~mm}$ interval from pith to barks and compressive strength was successively measured from pith to bark.

\section{Statistical analysis}

All statistical analysis was conducted by a software ( $\mathrm{R}$ version 3.2.1, $\mathrm{R}$ Core Team 2015). The differences of measured characteristics or properties among growth categories were detected by one-way analysis of variance test. In addition, the relationships between two measured characteristics or properties were evaluated by Pearson's correlation coefficient.

\section{RESULTS AND DISCUSSION}

\section{Anatomical characteristics and wood properties}

Mean values of stem diameter at $1.3 \mathrm{~m}$ above ground and stress-wave velocity of stem in the plot were $16.8 \mathrm{~cm}$ and $3.94 \mathrm{~km} \mathrm{~s}^{-1}$, respectively (Table 1 ). Based on the results of stem diameter, number of trees was 11, 29 and 10 for fast-, medium- and slow-growth categories, respectively. A significant difference was observed in stem diameter, whereas not in stress-wave velocity. In Tectona grandis planted in Indonesia, mean values of stress-wave velocity were 3.23 to $3.78 \mathrm{~km} \mathrm{~s}^{-1}$ for 15 clones of 12-year-old trees, and 3.07 to $3.39 \mathrm{~km} \mathrm{~s}^{-1}$ for 24 -yearold trees originating from 21 seed provenances (Hidayati et al. 2013a,b). The results obtained in the present study showed relatively higher values compared to those of teak trees.

Figure 1 shows radial variations of anatomical characteristics and wood properties. All anatomical characteristics and wood properties, except for cell wall thickness of wood fibre, increased from pith to bark. The tendency was the same for all radial growth categories.

Table 2 shows mean values of cell morphologies and wood properties in 15 selected trees. Mean values of vessel diameter, wood fibre diameter, cell wall thickness of wood fibre, wood fibre length and vessel element length were $201 \mu \mathrm{m}$, $13 \mu \mathrm{m}, 2.05 \mu \mathrm{m}, 1.05 \mathrm{~mm}$ and $0.21 \mathrm{~mm}$, respectively. In addition, mean values of basic density and compressive strength parallel to grain at green condition were $0.48 \mathrm{~g} \mathrm{~cm}^{-3}$ and 36.9 $\mathrm{MPa}$, respectively. Among the three categories, no significant differences were found in all cell morphologies and wood properties. In P. canescens, Ogata et al. (2008) reported that tangential diameter of solitary vessels in pore zone, cell wall thickness of wood fibre and wood fibre length of this species were up to 250 to $290 \mu \mathrm{m}, 3 \mu \mathrm{m}$, and 0.9 to $1.5 \mathrm{~mm}$ (1.2 $\mathrm{mm}$ in mean), respectively. On the other hand, Soerianegara \& Lemmens (1994) also reported that these values were 180 to $260 \mu \mathrm{m}, 3.5$ to $4.0 \mu \mathrm{m}$, and 0.9 to $1.6 \mathrm{~mm}$, respectively. In the present study, cell wall thickness of wood fibre showed relatively smaller value compared to those obtained by previous studies. It has been reported that the air-drying density of this species ranged from 0.35 to 0.73 (0.52 in mean) $\mathrm{g} \mathrm{cm}^{-3}$ (Soerianegara \& Lemmens 1994). Although the values of basic density (ratio of ovendrying weight to green volume) showed relatively lower values compared to air-drying density, the obtained results in the present study was similar to those reported by Soerianegara \& Lemmens (1994). On the other hand, Soerianegara \&

Table 1 Stem diameter and stress-wave velocity of trees in the plot

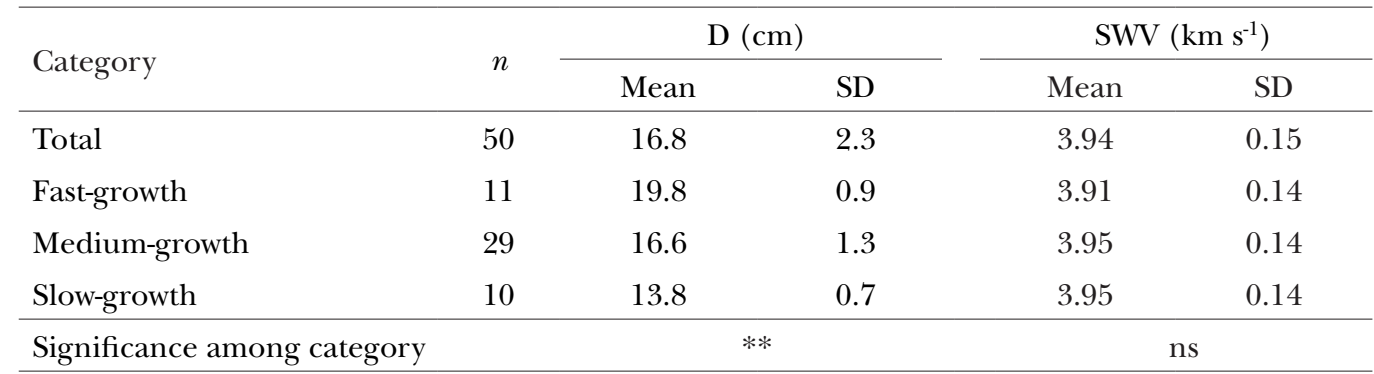

$n=$ number of trees, $\mathrm{D}=$ stem diameter at $1.3 \mathrm{~m}$ above ground, $\mathrm{SWV}=$ stress-wave velocity of stem, $\mathrm{SD}=$ standard deviation, $\mathrm{ns}=$ not significant, $* *=$ significant at $1 \%$ level 


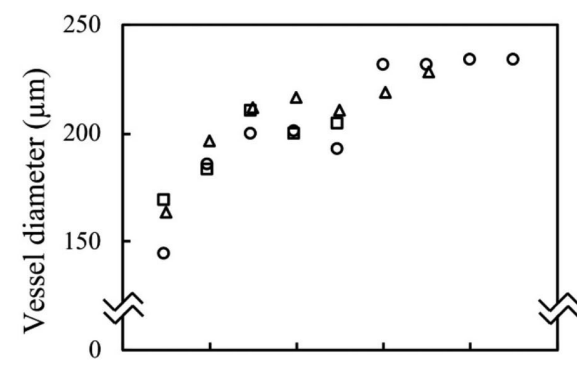

$\begin{array}{ll}\circ & \text { Fast growth } \\ \Delta \text { Medium grow }\end{array}$

$\square$ Slow growth
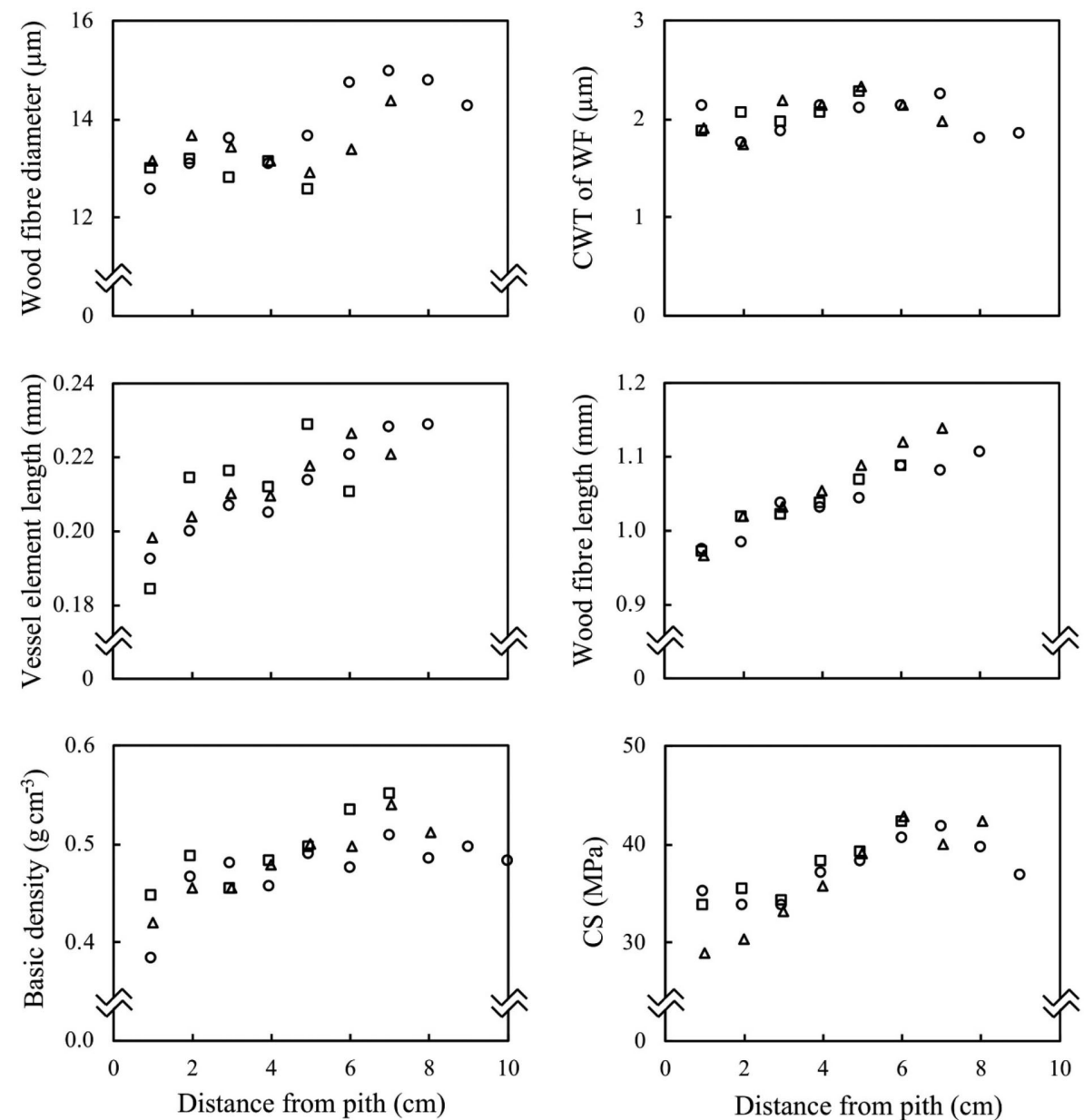

Figure 1 Radial variations of anatomical characteristics and wood properties; CWT of WF $=$ cell wall thickness of wood fibre, $\mathrm{CS}=$ compressive strength parallel to grain at green condition; the values of symbols in each graph were mean values of each growth category at a certain radial position

Lemmens (1994) reported that compressive strength parallel to grain at green condition was 25 $\mathrm{MPa}$. In the present study, relatively higher mean value (36.9 $\mathrm{MPa})$ was obtained in compressive strength parallel to grain at green condition.

\section{Relationships among anatomical characteristics and wood properties}

Table 3 shows correlation coefficients among cell morphologies and wood properties. Significant correlation was found between basic density and compressive strength $(\mathrm{r}=0.579)$. It is known that significant positive correlation was found between wood density and compressive strength (Kollmann \& Côté 1984). This tendency is also true for tropical-fast-growing tree species (Chowdhury et al. 2009, Ishiguri et al. 2012a, Pertiwi et al. 2018). The obtained results in the present study were similar to these reports, suggesting that mechanical properties of this species can be predicted by basic density. On the other hand, fibre wall thickness was also significantly correlated with fibre diameter 
Table 2 Mean values and standard deviation of growth characteristics, cell morphologies and wood properties in each category

\begin{tabular}{|c|c|c|c|c|c|c|c|c|c|}
\hline \multirow[t]{2}{*}{ Property } & \multicolumn{2}{|c|}{$\begin{array}{c}\text { Total } \\
(n=15)\end{array}$} & \multicolumn{2}{|c|}{$\begin{array}{l}\text { Fast growth } \\
\qquad(n=5)\end{array}$} & \multicolumn{2}{|c|}{$\begin{array}{l}\text { Medium growth } \\
\qquad(n=5)\end{array}$} & \multicolumn{2}{|c|}{$\begin{array}{l}\text { Slow growth } \\
\quad(n=5)\end{array}$} & \multirow{2}{*}{$\begin{array}{c}\text { Significance } \\
\text { among category }\end{array}$} \\
\hline & Mean & $\mathrm{SD}$ & Mean & $\mathrm{SD}$ & Mean & SD & Mean & $\mathrm{SD}$ & \\
\hline $\mathrm{D}(\mathrm{cm})$ & 16.8 & 2.5 & 19.6 & 0.4 & 16.9 & 0.6 & 13.9 & 0.6 & $* *$ \\
\hline $\mathrm{TH}(\mathrm{m})$ & 15.8 & 1.3 & 17.0 & 0.8 & 15.6 & 1.4 & 14.8 & 0.7 & $*$ \\
\hline $\mathrm{VD}(\mu \mathrm{m})$ & 201 & 12 & 202 & 8 & 207 & 5 & 194 & 16 & ns \\
\hline $\mathrm{FD}(\mu \mathrm{m})$ & 13 & 2 & 14 & 2 & 13 & 2 & 13 & 2 & ns \\
\hline FWT $(\mu \mathrm{m})$ & 2.05 & 0.36 & 2.01 & 0.41 & 2.08 & 0.39 & 2.05 & 0.34 & ns \\
\hline VEL (mm) & 0.21 & 0.01 & 0.21 & 0.01 & 0.21 & 0.01 & 0.21 & 0.01 & ns \\
\hline WFL (mm) & 1.05 & 0.03 & 1.05 & 0.04 & 1.06 & 0.04 & 1.03 & 0.01 & ns \\
\hline $\mathrm{SWV}\left(\mathrm{km} \mathrm{s}^{-1}\right)$ & 3.94 & 0.12 & 3.92 & 0.08 & 3.91 & 0.07 & 4.00 & 0.19 & ns \\
\hline $\mathrm{BD}\left(\mathrm{g} \mathrm{cm}^{-3}\right)$ & 0.48 & 0.02 & 0.47 & 0.03 & 0.48 & 0.02 & 0.49 & 0.02 & ns \\
\hline $\mathrm{CS}(\mathrm{MPa})$ & 36.9 & 1.6 & 37.4 & 1.5 & 36.4 & 1.4 & 37.0 & 2.1 & $\mathrm{~ns}$ \\
\hline
\end{tabular}

$n=$ number of trees, $\mathrm{SD}=$ standard deviation, $\mathrm{D}=$ stem diameter at $1.3 \mathrm{~m}$ above ground, $\mathrm{TH}=$ tree height, $\mathrm{VD}=$ vessel diameter, FD = wood fibre diameter, FWT = fibre wall thickness, VEL = vessel element length, $\mathrm{WFL}=$ fibre length, $\mathrm{SWV}=$ stress-wave velocity of stem, $\mathrm{BD}=$ basic density, $\mathrm{CS}=$ compressive strength, $\mathrm{ns}=\mathrm{not}$ significant, $*$ = significant at $5 \%$ level, $* *=$ significant at $1 \%$ level

Table 3 Correlation coefficients among cell morphologies and wood properties

\begin{tabular}{|c|c|c|c|c|c|c|c|c|}
\hline & VD & FD & FWT & VEL & WFL & SWV & $\mathrm{BD}$ & CS \\
\hline VD & & ns & ns & ns & ns & ns & ns & ns \\
\hline FD & -0.092 & & $* *$ & ns & ns & ns & ns & $\mathrm{ns}$ \\
\hline FWT & 0.026 & -0.866 & & ns & ns & ns & $*$ & ns \\
\hline VEL & 0.224 & 0.379 & -0.287 & & ns & ns & ns & ns \\
\hline WFL & 0.291 & -0.204 & 0.069 & -0.232 & & ns & ns & ns \\
\hline SWV & -0.418 & -0.047 & 0.085 & 0.064 & -0.010 & & ns & ns \\
\hline BD & -0.243 & -0.330 & 0.592 & -0.239 & -0.333 & -0.024 & & $*$ \\
\hline CS & 0.143 & -0.123 & 0.342 & 0.185 & -0.156 & -0.369 & 0.579 & \\
\hline
\end{tabular}

$\mathrm{VD}=$ vessel diameter, FD = wood fibre diameter, FWT = fibre wall thickness, VEL = vessel element length, $\mathrm{WFL}=$ fibre length, SWV = stress-wave velocity of stem, BD = basic density, $\mathrm{CS}=$ compressive strength, $\mathrm{ns}=$ not significant, $*$ = significant at $5 \%$ level, $* *=$ significant at $1 \%$ level; number of trees $=15$; lower diagonal and upper diagonals are correlation coefficients and significant levels, respectively

$(r=-0.866)$ or basic density $(r=0.592)$. Pertiwi et al. (2018) reported that a significant correlation $(\mathrm{r}=0.47)$ was found between fibre wall thickness and basic density in Neolamarckia cadamba trees planted in Indonesia. Similar results were also obtained in Eucalyptus tereticornis and Falcataria moluccana (syn. Paraserianthes falcataria) (Sharma et al. 2005, Ishiguri et al. 2009). It is considered that basic density of this species is closely related with fibre wall thickness rather than vessel diameter which sometimes affects wood density in hardwood species (Ishiguri et al. 2009).

\section{Effects of radial growth rate on anatomical characteristics and wood properties}

No significant or weak significant correlations were found between stem diameter and stresswave velocity of stem in tropical fast-growing tree species, such as F. moluccana, Acacia mangium, N. cadamba, Ochroma pyramidale, Azadirachta excelsa and Dysoxylum mollissimum (Ishiguri et al. 2007, Makino et al. 2012, Ishiguri et al. 2016, Wahyudi et al. 2016, Pertiwi et al. 2017a,b). Similar results were obtained in non-fast-growing tree species 
in the tropics (Ishiguri et al. 2012b, Hidayati et al. 2013a,b). As shown in Figure 2, no significant correlation was found between stem diameter and stress-wave velocity of stem. In addition, significant difference in stress-wave velocity was not found among three growth categories, by analysis of variance test (Table 1). These results suggest that trees with faster radial growth rate in this species do not always produce wood with lower Young's modulus. In addition, it has been reported that growth characteristics were not always related with anatomical characteristics and wood properties in tropical fast-growing tree species (DeBell et al. 2001, Wahyudi et al. 2001, Kojima et al. 2009a,b, Pillai et al. 2013, Ishiguri et al. 2016, Pertiwi et al. 2017a,b, 2018). There were no significant differences in anatomical characteristics and wood properties investigated in the present study among three growth categories (Table 2). No significant correlations were found between growth characteristics (stem diameter and tree height) and anatomical characteristics or wood properties (Table 4). It is considered, therefore, that anatomical characteristics and wood properties of slow-growing tree species may be independent from radial growth rate.

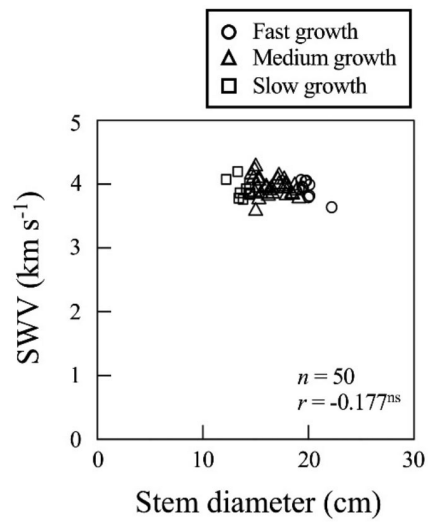

Figure 2 Relationship between stem diameter and stresswave velocity of stem; SWV = stress-wave velocity of stem, $r=$ correlation coefficient, $n=$ number of trees, $\mathrm{ns}=$ not significant

Table 4 Correlation coefficients between growth characteristics and cell morphologies or wood properties

\begin{tabular}{ccc}
\hline Property & $\begin{array}{c}\text { Stem diameter at } \\
1.3 \mathrm{~m} \text { above ground }\end{array}$ & Tree height \\
\hline VD & $0.242 \mathrm{~ns}$ & $0.165 \mathrm{~ns}$ \\
FD & $0.284 \mathrm{~ns}$ & $0.378 \mathrm{~ns}$ \\
FWT & $-0.121 \mathrm{~ns}$ & $-0.308 \mathrm{~ns}$ \\
VEL & $0.183 \mathrm{~ns}$ & $0.162 \mathrm{~ns}$ \\
WFL & $0.263 \mathrm{~ns}$ & $-0.020 \mathrm{~ns}$ \\
SWV & $-0.216 \mathrm{~ns}$ & $-0.240 \mathrm{~ns}$ \\
BD & $-0.300 \mathrm{~ns}$ & $-0.507 \mathrm{~ns}$ \\
CS & $0.062 \mathrm{~ns}$ & $0.057 \mathrm{~ns}$ \\
\hline
\end{tabular}

$\mathrm{VD}=$ vessel diameter, $\mathrm{FD}=$ wood fibre diameter, $\mathrm{FWT}=$ fibre wall thickness, VEL = vessel element length, WFL = fibre length, SWV = stresswave velocity of stem, $\mathrm{BD}=$ basic density, $\mathrm{CS}=$ compressive strength, $\mathrm{ns}=$ not significant; number of samples $=15$ 


\section{CONCLUSIONS}

Radial variations of anatomical characteristics and wood properties were investigated for 23-yearold $P$. canescens planted in Indonesia. Effects of radial growth rate were also discussed on the characteristics and the properties. Mean values of stem diameter at $1.3 \mathrm{~m}$ above ground and stresswave velocity of stem in the plot were $16.8 \mathrm{~cm}$ and $3.94 \mathrm{~km} \mathrm{~s}^{-1}$, respectively. All anatomical characteristics and wood properties, except for cell wall thickness of wood fibre, increased from pith to bark. Mean values of vessel diameter, wood fibre diameter, cell wall thickness of wood fibre, wood fibre length and vessel element length were $201 \mu \mathrm{m}, 13 \mu \mathrm{m}, 2.05 \mu \mathrm{m}, 1.05 \mathrm{~mm}$ and $0.21 \mathrm{~mm}$, respectively. In addition, mean values of basic density and compressive strength parallel to grain at green condition were $0.48 \mathrm{~g} \mathrm{~cm}^{-3}$ and 36.9 MPa, respectively. No significant differences among three growth categories were found in anatomical characteristics and wood properties, suggesting that anatomical characteristics and wood properties are independent from radial growth rate even in the relatively slow-growing tropical tree species.

\section{ACKNOWLEDGEMENTS}

The authors express sincere thanks to PT INHUTAN II for providing sample trees.

\section{REFERENCES}

Chowdhury MQ, Ishiguri F, Izzuka K et Al. 2009. Radial variations of wood properties in Casuarina equisetifolia growing in Bangladesh. Journal of Wood Science 55: 139-143. https://doi.org/10.1007/s10086-0081004-2.

DeBell DS, Keyes CR \& Gartner BL. 2001. Wood density of Eucalyptus saligna grown in Hawaiian plantations: effects of silvicultural practices and relation to growth rate. Australian Forestry 64: 106-110. https://doi.org /10.1080/00049158.2001.10676173.

Hidayati F, Ishiguri F, Iizuka K et al. 2013a. Variation in tree growth characteristics, stress-wave velocity, and Pilodyn penetration of 24-year-old teak (Tectona grandis) trees originating in 21 seed provenances planted in Indonesia. Journal of Wood Science 59: 512516. https://doi.org/10.1007/s10086-013-1368-9.

Hidayati F, Ishiguri F, Iizuka K et al. 2013b. Growth characteristics, stress-wave velocity, and Pilodyn penetration of 15 clones of 12-year-old Tectona grandis trees planted at two different sites in Indonesia. Journal of Wood Science 59: 249-254. https://doi. org/10.1007/s10086-012-1320-4.
Hidayati F, Ishiguri F, Makino K et al. 2017. The effects of radial growth rate on wood properties and anatomical characteristics and an evaluation of the xylem maturation process in a tropical fast-growing tree species, Gmelina arborea. Forest Products Journal 67: 297-303. https://doi.org/10.13073/FPJ-D-16-00027.

Ishiguri F, Aiso H, Hirano M ET AL. 2016. Effects of radial growth rate on anatomical characteristics and wood properties of 10-year-old Dysoxylum mollissimum trees planted in Bengkulu, Indonesia. Tropics 25: 23-31. https://doi.org/10.3759/tropics.25.23.

Ishiguri F, EizaWa J, SAIto Y et al. 2007. Variation in the wood properties of Paraserianthes falcataria planted in Indonesia. IAWA Journal 28:339-348. https:/ / doi. org/10.1163/22941932-90001645.

IsHiguri F, Hiraiwa T, IIZUKA K ET AL. 2009. Radial variation of anatomical characteristics in Paraserianthes falcataria planted in Indonesia. IAWA Journal 30: 343-352. https://doi.org/10.1163/22941932-90000223.

Ishiguri F, Hiraiwa T, Iizuka K et al. 2012a. Radial variation in microfibril angle and compression properties of Paraserianthes falcataria planted in Indonesia. IAWA Journal 33: 15-23. https://doi. org/10.1163/22941932-90000076.

Ishiguri F, Takeuchi M, Makino K et al. 2012b. Cell morphology and wood properties of Shorea accuminatissima planted in Indonesia. IAWA Journal 33: 25-38.

KARTAWINATA K. 1994. The use of secondary forest species in rehabilitation of degraded forest lands. Journal of Tropical Forest Science 7: 76-86.

Kojima M, Yamamoto H, Marsoem SN et al. 2009a. Effects of the lateral growth rate on wood quality of Gmelina arborea from 3.5-, 7- and 12-year-old plantations. Annals of Forest Science 66: 507.

Kojima M, Yamamoto H, Okumura K et al. 2009b. Effect of the lateral growth rate on wood properties in fast-growing hardwood species. Journal of Wood Science 55: 417-424.

Kollmann FFP, Côté WA JR. 1984. Principles of Wood Science and Technology, Volume 1: Solid Wood. Springer-Verlag, Berlin.

Lei H, Gartner BL \& Milota MR. 1997. Effect of growth rate on the anatomy, specific gravity and bending properties of wood from 7-year-old red alder (Alnus rubra). Canadian Journal of Forest Research 27: 80-85.

MAKINO K, IshigurI F, WAHYUdI I ET AL. 2012. Wood properties of young Acacia mangium trees planted in Indonesia. Forest Products Journal 62: 102-106.

Ogata K, FujII T, ABe H et AL. 2008. Identification of the Timbers of Southeast Asia and the Western Pacific. Kaiseisha Press, Ohtsu.

Ohbayashi H \& Shiokura T. 1990. Wood anatomical characteristics and specific gravity of fast-growing tropical tree species in relation to growth rate. Mokuzai Gakkaishi 36: 889-893.

Pertiwi YAB, Aiso H, Ishiguri F et AL. 2018. Radial variation of wood properties in Neolamarckia cadamba trees from an East Java community forest. Southern Forests 80: 351-359.

Pertiwi YAB, Aiso H, Ishiguri F et Al. 2017a. Effect of radial growth rate on wood properties of Neolamarckia cadamba. Journal of Tropical Forest Science 29: 30-36. 
Pertini YAB, Ishiguri F, Aiso H et al. 2017b. Wood properties of 7-year-old balsa (Ochroma pyramidale) planted in East Java. International Wood Products Journal 8 : 227-232.

Pillai PKC, Pandalai RC, Dhamodaran TK et al. 2013. Effect of silvicultural practices on fibre properties of Eucalyptus wood from short-rotation plantation. New Forests 44: 521-532.

R Core Team. 2015. R: A Language and Environment for Statistical Computing. R Foundation for Statistical Computing, Vienna. http://www.R-project.org/.

Sharma SK, Rao RV, ShukLa SR et al. 2005. Wood quality of coppiced Eucalyptus tereticornis for value addition. IAWA Journal 26: 137-147.

Soerianegara I \& Lemmens RHMJ. 1994. Plant Resources of South-East Asia 5(1) Timber Trees: Major Commercial Timbers. Prosea, Bogor.
Wahyudi I, Ishiguri F, Makino K et Al. 2016. Evaluation of xylem maturation and the effects of radial growth rate on anatomical characteristics and wood properties of Azadirachta excelsa planted in Indonesia. Journal of the Indian Academy of Wood Science 13: 138-144.

Wahyudi I, OkuYama T, Hadi YS et al. 2001. Relationship between released strain and growth rate in 39-yearold Tectona grandis planted in Indonesia. Holzforschung 55: 63-66.

ZHANG SY. 1995. Effect of growth rate on wood specific gravity and selected mechanical properties in individual species from distinct wood categories. Wood Science and Technology 29: 451-465.

ZoBel BJ \& VAN BUIJTENEN JP. 1989. Wood variation: Its causes and control. Springer-Verlag, Berlin. 